\title{
The Study of Judges' Disparity in Corruption Cases in Indonesia
}

\author{
Hamidah Abdurrachman*, Fajar Dian Aryani \\ Faculty of Law \\ Universitas Pancasakti Tegal \\ Tegal, Indonesia \\ *h-abdurrachman@upstegal.ac.id
}

\author{
Nayla Majestya \\ School of Design \\ Bina Nusantara University \\ Jakarta, Indonesia
}

\begin{abstract}
Disparity in decision often occurs in corruption cases because the judges have their own independence to decide corruption cases without full consideration. For example, people with the same case and position, but they can get a different sentence. It is impossible to omit disparity but the number of disparity can be reduced to give equal justice for the perpetrators and victims of corruption. Disparity is an inequality in criminal sentencing which is the result of unfair or unexplained causes, rather than a legitimate use of discretion in the application of the law. This article aims to analyse the corruption decision trends in Indonesia and disparity factors. This study used normative legal research as the research method. The writers gain data from the literature review. To ensure the data, the writers used triangulation. The findings of this study are that the judges' decision on corruption cases vary in each level and the factors of judges' disparity are influenced by inter-jurisdictional disparity, intra-jurisdictional disparity, or intra-judge disparity.
\end{abstract}

Keywords: corruption, disparity, judge decision

\section{INTRODUCTION}

Corruption is not a new phenomenon. Communities have lived with small corruption for a long time ago [1]. Corruption is like a disease, and Indonesia is one of the countries that has that disease. Tiihonen argued that corruption is a disease of public power and indicates bad governance [2]. When some people do many ways to give heavy sentence to the corruptor, the judiciary raises the problem of disparity. Criminal disparity is a criminal inequality between similar offenses in similar conditions or situations (comparable circumstances) [3].

At least, there are two reasons why disparity is an important part to get more attention. First, disparity in the verdict will ultimately injure the sense of justice. Second, in a certain condition, disparity in the verdict is caused by buying and selling decision because judges have their own independence to run their authority. Judges' decision must reflect justice for all parties, and give legal certainty [4]. Normatively, criminal disparity comes from judges' discretion in the form of judges' conviction. Disparity makes the public hesitate the court's decision because it opens the opportunity for corruptors to get a light sentence. In practice, judges not only sentence below the normative maximum provisions of the law, they also create disparity. Criminal disparity related to the personality, values and attitudes of judges. They need careful consideration and thought to determine a decision [5].

Decisions of judges are judges' statements which are set forth in written form and pronounced in open court to the public as the result of lawsuit examination (contingent). Judges as state officials have the authority to settle cases. All parties must obey judges' decisions because they have forced power. Another term used to refer to a judge's decision is a court decision. Judge's decision or a court decision is a work to find law [6]. The question is why the same judges impose different sentences on the cases with the same characteristics. For example: the different verdict in the case of M. Nazaruddin and Angelina Sondakh is based on the indictment of the public prosecutor and the facts in the trial, such as witnesses' statements, statements of the defendant and other evidence. In each article which is prejudges and proven in the court, it has different criminal threats, like a minimum and the maximum limit, so the judges can decide the cases [7].

According to Cassia, the reason why the sentence can be different is usually caused by differences in personal mitigation (extra-legal factors) [8]. Spohn found cases in the United States that the judges used personal mitigation (extra-legal factors) that discriminates (for example: race, ethnicity, religion, etc.) If this happens, the disparity is categorized as the actions that cannot be accounted for [8]. Judicial practice in corruption cases often results in criminal disparities in relation to the length of the criminal sentence, criminal types, and the practice of implementing the crime.

Finally, the way to make the corruptors deterrent will become a discourse among law enforcement officers. It can be seen from 2017 to 2019 period, there are differences in the average imprisonment sentences at each level of court in Indonesia where the average imprisonment sentences at the District Court level is only 2 years and 3 months, the High Court is 2 years and 8 months, and the Supreme Court is 5 years and 9 months. Criminal disparities without the base or reasons will create a negative impact on the law enforcement process. Public dissatisfaction as justice seekers leads to distrust in the criminal justice system.

Judges or court decisions are sometimes different for the same case. The difference in decisions is called disparity or ambiguity. The judge's decision is an open text that anyone can 
interpret, even though the binding power is only for the parties [9]. Many experts paid more attention to the problem of disparity among judges' decisions for long periods. Disparity can be found not only in Indonesia but also in many countries [10]. Disparity as an issue can interfere with the justice system. Besides, public will assume disparity as legal injustice and it makes the public pessimism toward the judiciary. Although judges have independence but it has a limit. There is a principle of nulla poena sine lege that gives a limit to the judge to sentence. However, although it has a measurement, disparity problems will still occur if there is a wide gap between the minimum and maximum criminal [11].

As stated by Frisch, "disparity in the apportionment of sentences was not a transitional phenomenon on the way to a soon-to-be-achieved uniformity but a permanent state of affairs in criminal sentencing practice" [12]. Hence, the problem of disparate sentences is not exclusively found in corruption cases. We can see the example of disparity in corruption cases in Indonesia in the bribery case for the election of the Senior Deputy Governor of Bank Indonesia. In that case, at least 29 (twenty-nine) Members of the Indonesian House of Representatives (DPR-RI) were involved. However, imprisonment sentenced to recipients of bribes is not the same even though the role of the recipient is relatively the same: they received money/promises to elect Miranda Gultom as Senior Deputy Governor of Bank Indonesia.

In corruption cases, the phenomenon of criminal disparity is not only limited to basic crime but also it includes the criminal substitute money. As we know, criminal replacement money is a specialty of corruption cases. In the implementation, it is common to find the phenomenon of disparity in corruption cases by sentencing the corruptors with the criminal replacement money. The research notes found a corruption case convicted of paying a replacement money of Rp. 50 million (fifty million rupiah) with a substitute prison sentence (if the convicted person cannot pay replacement money) for 12 (twelve) months. Whereas in other cases, the Panel of Judges ruled that a replacement money of Rp. 378.11 billion (three hundred seventy-eight point eleven billion rupiah) with the imprison sentence from replacement money for 12 (twelve) months [13].

Frisch asserted that the reason why disparity is unacceptable is that it is "incompatible with the constitutional rights to equal treatment and to justice" [12]. Disparity of sentences also sends inconsistent and irrational signals to the public, hence "they are serious impediments to positive general prevention by reinforcing respect for the law". The disparity of sentences makes the reintegration of offenders more challenging. Unjustified sentences can heighten the offender's antagonism toward society and distrust towards the administration of the legal system. Thus, disparity considerably harms the prisoner and the prison system. Responding to this, Corruption.

The behavioural definition of corruption as the misuse of entrusted public office for private gain is a commonly used an explanation of corruption [14]. It refers to "the proactive behaviour of public officials to extort or seek bribes for activities and services that they have been entrusted to perform, the use of personal influence or connections to get something accomplished outside of the legally sanctioned channels and the breach of standards of conduct that may result in personal conflicts of interest" [15].

The phenomenon of corruption, in many cases, is cultural or customary to get things done. Those practicing such cultures rarely see real harmony in their actions. But often, small acts of corruption can accumulate to a major harm that endangers life. In another side, Shah argued that corruption can include three broad categories [16]: First, grand corruption, several officials steal or abuse large amounts of public resources; Second, state or regulatory capture, several public and private institutions get in touch in collusion relationship to commit several frauds for personal gain; and third, bureaucratic or petty corruption, the involvement of many public officials in using positions to get little bribes or money [16].

Elite officials usually do grand corruption and state or regulator capture. Political elites or senior officials hold and plan the policy or regulation for their interest or colleagues, so it is possible for officials or policymakers to get the advantages, a huge income, and other facilities and to accept bribes from national or transnational level companies. State capture can occur in various forms. World bank in its book "Anti-Corruption in Transition 2" explains several forms of state capture, such as (1) The bribe for members of House of Representatives to influence legislation; (2) The bribe for state officials to influence public policy; (3) The bribe for the judiciary to influence decisions related to large cases; (4) The bribe to central bank officials to influence monetary policy; and (5) Donations of illegal campaigns for political parties [17]. Meanwhile, civil servants usually did Bureaucratic/Petty Corruption as part of policy implementation. Corruption can usually occur in the public service sectors, for example in immigration services, police, hospitals, taxes, schools and licensing [17].

There are limited studies that concern on disparity in Indonesia. The writers found a study on judges' disparity conducted by Arifuddin [18]. Their study revealed that how disparity can happen in judging in Makassar or Bandung. Other studies conducted by Lalitasari [19] or Krishnanda [20]. Most of the studies explained how judges' disparities happened in certain region and cases. While this study conveys wide thought on judges' decision on corruption cases and the factors behind judges' disparities in Indonesia. So, this this study contributes for laws studies and fill the gap about the information of disparities in Indonesia.

Nowadays, Indonesian people hope that corruptors will get a heavy sentence. They always voice to eradicate corruption as the political jargon. This hope looks like a mirage. It looks beautiful, but it is only a shadow and is difficult to realize. Even, sometimes the public know that corruptors get minimum sentence, so they can easily enjoy their result of corruption. Based on this highlight in this introduction, the writers formulate research statement as follows: 1) how is the trend of judges' decision in deciding corruption cases in Indonesia; and 2) What are the factors of disparity in judges' decisions? 


\section{METHOD}

This study is normative legal research or dogmatically legal research that focuses on the legal as a system that consists of a set of legal principles, legal norms, and legal rules [21]. This study is normative research because the object of this research is purely normative law with secondary data targets in the form of primary and secondary legal materials [22].

The writer collected the data through a literature study. The data used are secondary data. Then they are grouped into primary legal materials and secondary legal materials. To obtain valid data, the writer used triangulation [23]. The writer used triangulation to compare and cross check the data. After writer got the valid data, the writer conducted focus group discussion with the experts in disparity materials. To analyse the data, the writer did three steps: editing, coding, and tabulating. In this step, the writer grouped the answers carefully, thoroughly, and regularly.

\section{RESUltS AND DisCUSSION}

\section{A. Judge's Decision in Corruption Cases in Indonesia}

In 2018, the Indonesian Corruption Watch collected 1053 corruption cases with 1162 offenders. The data is collected from the District Court's, High Court's, and Supreme Court's decisions. From this data, the average duration of imprisonment decided for corruption case offenders during 2018 is the two-year and five-month long, as shown by the table below [24]:

TABLE I. JUDGE'S DECISION

\begin{tabular}{|c|c|c|}
\hline No & Courts & The average sentence \\
\hline 1 & $\begin{array}{l}\text { District Court (with the } \\
\text { special judge for the } \\
\text { corruption case) }\end{array}$ & Two years and three months \\
\hline 2 & High court & Two years and eight months \\
\hline 3 & Supreme Court & Five years and nine months \\
\hline
\end{tabular}

From 1053 cases with 1162 offenders in 2018, the District Court decided on 926 offenders (79.69\%), the High Courtside on 208 offenders $(17.90 \%)$, and the Supreme Court decided on 28 offenders $(2.41 \%)$. The total state's financial loss is IDR $119,884,000,000$ (US \$ 8,565,293).

The table below shows more details on the variety of sentences decided by each court:

TABLE II. THE VARIETY OF SENTENCES DECIDED BY EACH COURT

\begin{tabular}{|l|l|l|l|l|l|l|l|}
\hline \multicolumn{2}{|c|}{} & \multicolumn{2}{c|}{ District Court } & \multicolumn{2}{c|}{ High Court } & \multicolumn{2}{c|}{ Supreme Court } \\
\hline \multicolumn{1}{|c|}{ Sentence Category } & Total Offenders & Offenders & $\%$ & \multicolumn{1}{c|}{ Offenders } & \% & Offenders & \% \\
\hline Light & 918 & 749 & 81,59 & 159 & 17,32 & 10 & 1,09 \\
\hline Moderate & 180 & 131 & 72,78 & 35 & 19,44 & 14 & 7,78 \\
\hline Heavy & 9 & 3 & 33,33 & 3 & 33,33 & 3 & 33,33 \\
\hline Unproven & 26 & 21 & 80,77 & 4 & 15,38 & 1 & 3,85 \\
\hline Mistaken & 1 & 0 & 0,00 & 1 & 100,00 & 0 & 0,00 \\
\hline Identified & 14 & 9 & 64,29 & 5 & 35,71 & 0 & 0,00 \\
\hline $\begin{array}{l}\text { Under the minimum } \\
\text { punishment }\end{array}$ & 11 & 10 & 90,91 & 1 & 9,09 & 0 & 0,00 \\
\hline N.O & 3 & 3 & 100,00 & 0 & 0,00 & 0 & 0,00 \\
\hline
\end{tabular}

The table reflects that most sentencing decisions in the District Court and High Court levels for corruption cases are considered light (1-year - 4-year long imprisonment). While in the Supreme Court level, most sentences are decided in the moderate category (4-year - 10-year long imprisonment). According to [21] this trend is not different from what happened in 2016 - 2017.

The following is a general description of the categories of decisions on corruption in the Corruption Court of the first level, the Court of appeal, and the Supreme Court in 2017:

TABLE III. DECISIONS ON CORRUPTION IN THE CORRUPTION COURT OF THE FIRST LEVEL, THE COURT OF APPEAL, AND THE SUPREME COURT IN 2017

\begin{tabular}{|l|l|l|}
\hline \multicolumn{1}{|c|}{ Sentence Category } & Total Offenders & Percentage \\
\hline Light (1-4 years) & 1.127 & $81,61 \%$ \\
\hline Moderate (>4-10 years) & 169 & $12,24 \%$ \\
\hline Heavy (>10 years) & 4 & $0,29 \%$ \\
\hline Free & 35 & $2,53 \%$ \\
\hline Unidentified & 45 & $3,26 \%$ \\
\hline N.O & 1 & $0,07 \%$ \\
\hline Total & $\mathbf{1 . 3 8 1}$ & $\mathbf{1 0 0 \%}$ \\
\hline
\end{tabular}

The following is a general description of the categories of decisions on corruption in the Corruption Court of the first level, the Court of Appeals, and the Supreme Court in 2018:

TABLE IV. DECISIONS ON CORRUPTION IN THE CORRUPTION COURT OF THE FIRST LEVEL, THE COURT OF APPEALS, AND THE SUPREME COURT IN 2018

\begin{tabular}{|l|l|}
\hline \multicolumn{1}{|c|}{ Sentence Category } & \multicolumn{1}{c|}{ Total Offenders } \\
\hline Light (1-4 years) & 918 \\
\hline Moderate (>4-10 years) & 180 \\
\hline Heavy (>10 years) & 9 \\
\hline Free & 26 \\
\hline Unidentified & 14 \\
\hline Free & 1 \\
\hline N.O & 1 \\
\hline Under the minimum punishment & 11 \\
\hline
\end{tabular}

Since 2017, there has been a trend of imprisonment under the minimum punishment in the Corruption Act. The trend arose as a result of repression of illegal levies, where imprisonment ranged from the 3-month to 1-year, with illegal levies starting from hundreds of thousands of rupiah (Rp. 270,000) to tens of millions of rupiah (Rp. 15,000,000). The 
N.O. decision is Niet Ontvankelijke Verklaard, or a decision issued by a court because of a formal flaw in the prosecutor's indictment. There was a significant increase in the average verdict at Supreme Court in 2017 and 2018. It becomes the 5year in 2017 and it increased 9 months in 2018, the 5-year and 9-month.

\section{B. The Factors that Cause the Disparity of Judge Decisions in Indonesia}

Judges as officials is central of attention because they decide a sentence to the offenders in a court and they are also people who make a disparity. In deciding a case, judges used many considerations so they can make disparity especially in corruption cases. Based on the results of the research, there are three types of criminal disparity: 1) Inter-jurisdictional Disparity. It occurs when the court jurisdictions have a different pattern of sentence caused by a different scale of a case from one region to another. For instance, the value of corruption, Rp. 10 billion, in Jakarta will be different with the same value in Papua. Therefore, the judges can sentence differently although it has the same characteristics. The different sentence can be caused by the different standard living needs and the valuation of currencies between Jakarta and Papua. 2) Intra-jurisdictional Disparity. It occurs when there is the different decision in a case with the same typology and characteristics because the judges have different perceptions in seeing the scale of criminal [25]. So different judges can sentence the actors differently with a similar criminal act. For example, in a court, the judges in the region can sentence differently for the criminal act that has the same characteristics. Besides, this difference can be caused by the different background of judges like female judges will sentence heavily than male judges when they face sexual violence [8]. 3) Intra-judge Disparity. It occurs when judges are insistent in deciding a case. For example, the judges sentence the offender 2-year imprisonment, but in another case with the same characteristics, the judges sentence the offender 10-year imprisonment. Based on Spohn's findings, these disparities can be indicators of discrimination in decision. It is caused by how it is possible for judges to sentencing differently for the same act in context. Illegal extra-legal factors (for example: ethnicity, skin colour, religion, economic level, etc.) almost influence most of these types of disparities

\section{The Absence of Variables and Quantification Measurement of Prosecution that Reduces the Level of Disparity Objectively}

The judiciary which is assumed as the institution that has the clear and firm guidelines related to the determination of the amount of punishment, especially in corruption cases, is still susceptible although the Attorney General issued the Circular of the Attorney General No. 003/A/JA/02/2010 on the Guidelines of Lawsuit in Corruption Cases. It aims to prevent and minimize disparity in criminal charges by classifying the amount of state losses and the percentage of return factors (call variable) committed by the defendant with the number of criminal charges that prosecutor can prosecute. The prosecutors who handle the case cannot make a threat of prosecution for defendant but they can make it if they have a clear reason and permission from the leader.

Considering that the variable used in the Circular is only the amount of state loss and repayment of state funds by the defendant, this Circular can only be used for corruption cases with Article 2 and Article 3 of Law No. 31 of 1999 juncto Law No. 20 of 2001 on Eradication of Corruption Crimes. The Prosecutor cannot enforce bribery, gratuity, tender conspiracy, or other corruption cases regulated in Law No. 20 of 2001.

The disadvantage is the regulated variable is too specific so it cannot regulate the uniqueness of technical things or personal in each case. For example, there are two different cases that inflict a financial loss of a state in the amount of Rp. 10 billion. The two defendants don't recover a financial loss of a state but one corruption case doesn't impact seriously while another corruption case has a serious impact to public (pension fund corruption, social security fund corruption, etc.) So the question is whether they sit in the same periodic table of corruption.

Corruption Eradication Commission (KPK) with the work system is to equate the mindset of law enforcers so it is easy to maintain parity in prosecuting. To determine the amount of the indictment, all members of the team propose estimation number of indictment for defendants, then it will be calculated to take the average. The prosecutors consider factors that that incriminate and ease to determine criminal treat. The prosecutors, who handle a case in KPK, have the benchmark in the form of indictment precedent used as a reference to determine incriminating factors and easing factors by looking at previous claims that have been proven in court. Besides, the prosecutors can also give new variable to incriminate and ease or even it is in contradiction with the existing pattern or precedent. This is also vulnerable because it must be accountable and have reasons rational.

The Supreme Court has gone one step further to maintain the unity of the application of the law and the consistency of decisions by placing supreme judges with certain competencies and expertise in a case chamber, to ensure the consistency of judges' interpretation of the room to create legal unity for the handled cases, no exception for corruption cases. But until now there has been no regulation related to benchmarks or guidelines to determine the amount of indictment issued by the Supreme Court, especially for corruption cases.

\section{CONCLUSION}

- There is different average in judges' decision in each level of the court such as the duration of imprisonment decided for corruption case offenders in District Court, High court, and Supreme Court.

- Disparities occur because of different views or standards among the judges in deciding corruption cases, because they have their own independence and freedom of judges. There are three factors that influence judges' disparity such as inter-jurisdictional disparity, intra-jurisdictional disparity, or intra-judge disparity. 


\section{ACKNOWLEDGMENT}

The writers would like to thank to all parties who helped them to conduct this research, especially for DIKTI that has funded this research based on Surat keputusan nomor 327/M/KTP/2019 dan perjanjian/kontrak nomor 011/L6/AK/SP2H.1/PENELITIAN/2019.

\section{REFERENCES}

[1] K. Koutsoukis, "Patterns of corruption and political change in modern Greece 1946-1987," Corruption and Reform, vol. 4, pp. 1-13, 1989.

[2] S. Tiihonen, Central Government Corruption in Historical Perspectives, in Tiihonen, S. (ed.), The History of Corruption in Central Government. Amsterdam: IOS Press, pp. 1-36, 2003.

[3] Litbang Mahkamah Agung, Kedudukan dan Relevansi Yurisprudensi untuk Mengurangi Disparitas Putusan Pengadilan. Jakarta: Puslitbang Hukum dan Peradilan Mahkamah Agung Republik Indonesia, 2010.

[4] H. Girsang, "Disparitas Putusan Hakim Dan Faktor Penyebab Terjadinya Disparitas Dalam Putusan Hakim Pengadilan Tindak Pidana Korupsi Di Pengadilan Negeri Klas Ia Jayapura Terhadap Tuntutan Pasal 3 UU TIPIKOR", Jurnal Hukum dan Masyarakat, vol. XIII, no. 3, pp. 387-405, 2014.

[5] V.S. Yuliati and Y. Yanto, "Disparitas Putusan Hakim dalam Perkara Tindak Pidana Asusila Dengan Anak Sebagai Korbannya di Pengadilan Negeri Sleman”, Jurnal Kajian Hasil Penelitian Hukum, vol. 1, no. 2, pp. 46-65, 2017.

[6] L. Mulyadi, Putusan Hakim dalam Hukum Acara Pidana. Bandung: PT. Citra Aditya Bakti, 2007.

[7] T. Krisnanda, "Analisis Disparitas Putusan Hakim Terhadap Tindak Pidana Korupsi Kasus Wisma Atlet (Studi Putusan No. 1616K/Pid.Sus/2013 \& No. 2223 K/Pid.Sus/2012)", Jurnal Fakultas Hukum Universitas Lampung Bandar Lampung, 2015.

[8] C.S. Cassia, How do Judge Decide: The search for Fairness and Justice in Punishment. Washington: Sage Publication, 2008.

[9] Komisi Yudisial, Disparitas Putusan Hakim; Identifikasi dan Implikasi. Jakarta: Sekretaris Jenderal Komisi Yudisial Republik Indonesia, 2014.

[10] A. Anshworth, Sentencing and Criminal Justice. New York: Cambridge University Press, 2005.

[11] A. Zulfa, Perg eseran Paradigma Pemidanaan. Bandung: Lubuk Agung, 2011.
[12] W. Frisch, "From disparity in sentencing towards sentencing equality: The german experience," Criminal Law Forum, vol. 28, no. 3, pp. 437 $475,2017$.

[13] Indonesian Corruption Watch Studi Atas Disparitas Putusan Pemidanaan Perkara Tindak Pidana Korupsi. Jakarta: Policy Paper [Online]. Retrieved from: https://antikorupsi.org/id/news/studi-atasdisparitas-putusan-pemidanaan-perkara-tindak-pidana-korupsi, 2014.

[14] U.S. Agency for International Development, USAID Anticorruption Strategy. Washington, DC: USAID [Online]. Retrieved from: https://www.usaid.gov/sites/default/files/documents/1868/200mbo.pdf, 2005.

[15] B.I. Spector, Detecting Corruption in Developing Countries : Identifying Causes/strategies for Action (Vol. 1st ed). Sterling, Va: Kumarian Press [Online]. Retrieved from: http://eesources.perpusnas.go.id:2124/login.aspx?direct=true $\& \mathrm{db}=\mathrm{nlebk}$ \&AN=440899\&site $=$ eds-live, 2012.

[16] A. Shah, "Combating Corruption: Look Before You Leap", Finance and Development 4, vol. 41, 2012

[17] W. Wijayanto, Korupsi Mengkorupsi Indonesia Sebab, Akibat, dan Prospek Pemberantasan. Jakarta: PT. Gramedia Pustaka Utama, 2009.

[18] A. Arifuddin, "Disparity of punishment at The Court of The Crime of Corruption", Journal of Humanity, vol. 3, no. 2, pp. 16-28, 2015.

[19] L. Lalitasari, "Disparitas Pidana Putusan Hakim Dalam Kasus Korupsi Yang Dilakukan Secara Bersama-Sama Di Pengadilan Negeri Tindak Pidana Korupsi Semarang," Diponegoro Law Journal, vol. 8, no. 3, 2019.

[20] K. Krishnanda, Analisis Disparitas Putusan Hakim Terhadap Tindak Pidana Korupsi Kasus Wisma Atlet (Studi Putusan No. 1616 K/Pid.Sus/2013 \& No. 2223 K/Pid.Sus/2012), 2015. Unpublished.

[21] S. Soekanto and S. Mamudji, Penelitian Hukum Normatif Suatu Tinjauan Singkat. Cetakan ke - 11. Jakarta: PT Raja Grafindo Persada, 2009.

[22] M.H. Mezuk, "Jenis, Metode dan Pendekatan dalam Penelitian Hukum,' Jurnal Law Review, vol. V, no. 3, pp. 85-97, 2006.

[23] N.K. Denzin and Y.S. Lincoln, Handbook of Qualitative Research Terjemah. Yogyakarta: Pustaka Pelajar, 2010.

[24] Indonesian Corruption Watch, Tren Vonis Kasus Korupsi 2018. Policy Paper. Indonesia: Jakarta [Online]. Retrieved from: https://www.antikorupsi.org/sites/default/files/narasi tren vonis 2018.p df, 2018 .

[25] S. Krasnostein and A. Freiberg, "Pursuing Consistency in An Individualistic Sentencing Framework; If you Know Where You're Going, How Do You Know When You've Got There?" Law and Contemporary Problems, vol. 76, pp. 265-288, 2013. 